\title{
Cultivation, proximate composition and preliminary phytochemical analysis of wheat grass (Triticum aestivum L.) powder
}

\begin{abstract}
Namrata Jain, Mamta Singh and Neelam Chaturvedi
Wheat grass (Triticum aestivum) is a humble weed a power house of nutrient and vitamin supplements. Its main component is chlorophyll which is around 70 per cent. This can be consumed both in raw juice and powdered form. Considering its nutritional completeness and possible health implications of being blood builder, antioxidant, antiager, cell rejuvenator, cancer inhibitor, immune system supporter the study was undertaken to estimate nutritional composition and qualitative phytochemical analysis of wheat grass powder. About $100 \mathrm{~g}$ wheat grass powder was obtained from $1 \mathrm{~kg}$ of fresh wheat grass. Nutrient composition of wheat grass powder (WGP) was found to be impressive with protein content $25 \mathrm{~g}$ per cent, fibre $30 \mathrm{~g}$ per cent. Values of mineral ash, carbohydrate, moisture and fat were recorded as $4.8 \mathrm{~g}, 33.7 \mathrm{~g}, 6.3 \mathrm{~g}$ and $0.2 \mathrm{~g}$, respectively. Preliminary phytochemicals screening indicated the presence of Terpenoids, alkaloids, tannins, saponins, and sterols. The chlorophyll estimation indicated wheat grass powder contains $525 \mathrm{mg}$ of chlorophyll in $100 \mathrm{~g}$ of $T$. aestivum powder. Thus, it can be concluded that plant based wheat grass is an ideal supplement for general health and well being with therapeutic uses. It has an immense potential in the main stream of food processing industries as a health benefactor which proves to be beneficial for the society in prevention from life threatening diseases.
\end{abstract}

Key Words : Triticum aestivum, Nutritional composition, Phytochemicals, Wheat grass powder (WGP)

How to cite this article : Jain, Namrata, Singh, Mamta and Chaturvedi, Neelam (2019). Cultivation, proximate composition and preliminary phytochemical analysis of wheat grass (Triticum aestivum L.) powder. Food Sci. Res. J., 10(2): 189-192, DOI : 10.15740/ HAS/FSRJ/10.2/189-192.Copyright@ 2019: Hind Agri-Horticultural Society.

Email: jainnamrata.23@gmail.com

Mamta, Singh and Neelam, Chaturvedi, Department of Food and Nutrition, College of Home Science, Swami Keshwanand Rajasthan Agricultural University, Bikaner (Rajasthan) India 